J. Perinat. Med. 15 (1987) 193

\title{
Morphometric investigations of terminal villi of diabetic placentas in relation to the White classification of diabetes mellitus
}

\author{
Frank Stoz, Roland A. Schuhmann, and Adelheid Schmid
}

Section of Gynecologic Morphology, Department of Obstetrics and Gynecology, University of Ulm, West Germany

\section{Introduction}

The fetal risk in maternal diabetes mellitus is high $[5,6]$. The reasons for fetal macrosomatia are controversially as are those for intrauterine fetal growth retardation and intrauterine fetal death. These mostly happen without prodromes and are feared by all obstetricians. Morphologists have described signs of a so-called chronic placental insufficiency in cases of small for date infants and signs of a so-called acute placental insufficiency in cases of sudden intrauterine fetal death. In recent studies no distinct differences in the morphology of normal placentas and diabetic placentas have been described.

In this study have tried to determine by means of histometry, if there are specific and distinct changes in the morphology of terminal villi of the diabetic placenta which can explain the high fetal jeopardy. We also studied, whether the degree and course of diabetes mellitus influences the morphology of the terminal villi.

\section{Material and methods}

Twenty-two placentas of pregnancies with maternal diabetes mellitus classified according to WHiTE [17] were compared to 22 placentas of uncomplicated pregnancies. Delivery occured after the 37th gestational week in all cases. In the control group the neonates were mature, the $\mathrm{pH}>7.25$, and Apgar scores were 8 to 10 .

\section{Curriculum vitae}

Frank Stoz was born on January 25, 1950 in $R a$ vensburg. He first studied biology, and then medicine, with medical registration and doctoral dissertation in 1980 on the topic of morphometric studies in the human placenta.

He began his residency at the Department of Obstetrics and Gynecology at the

University of Ulm in 1980. Since 1985, he has specialized in gynecology and obstetrics with scientific work and publications on morphometric investigations in normal and pathological placentas and on diabetes mellitus in pregnancy.

The placentas were histologically processed as described in detail elsewhere [8]. In each of two histologic sections from each placenta, 50 terminal villi from the periphery of the placentones [10] representing the area of maternalfetal circulation were measured. The histometry was done with a semi-automatic Kontron Videoplan unit equipped with a special soft-ware program, developed for our studies. This has been described in previous publications $[8,14]$.

Statistical analyses were performed on the TR 440 (Siemens) at the Computer Center of the University of Ulm. 
The following parameters were measured:

- cross sectional surface and circumference of the terminal villi as they were classified in three groups $\left(<3000 \mu^{2},>6000 \mu^{2}\right)$

- cross sectional surfaces, circumferences and number of the villous vessels

- length and number of the epithelial plates

From the aforesaid parameters the following were calculated:

- degree of vascularization (of all cross sectional sections of the vessels: cross sectional surface of the villus)

- epithelial plates in proportion of the villous circumference (structures are explained in figure 1).

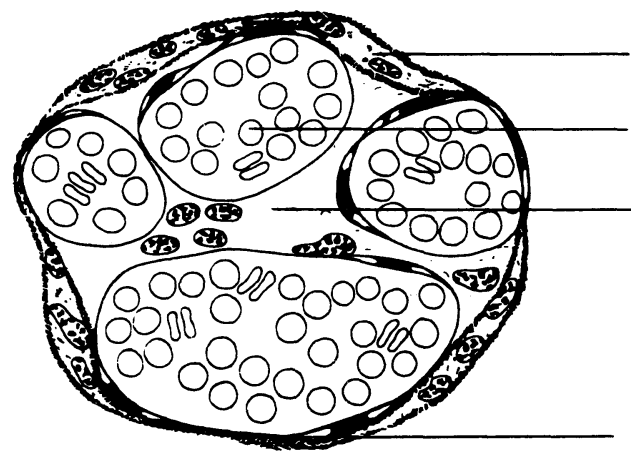

Figure 1. Histological structures of a mature terminal villus: sinusoidal formed villous vessel (1), thin exchange membrane epithelial plate (2), syncytium (3), villous stroma (4).

Table I. Results of histometric measurements, normal compared with diabetic placentas and classified to White; size of terminal villi.

\begin{tabular}{lll}
\hline & $\begin{array}{l}\text { Cross section sur- } \\
\text { face of terminal } \\
\text { villi }\left(\mu^{2}\right)\end{array}$ & $\begin{array}{l}\text { Circumference } \\
\text { of terminal } \\
\text { villi }(\mu)\end{array}$ \\
\hline $\begin{array}{l}\text { Normal } \\
\text { Diabetes }\end{array}$ & 2150 & 172 \\
Complete & 2484 & 183 \\
$\mathrm{p}<0.05$ & $\mathrm{p}<0.01$ \\
\hline White A & 2413 & 180 \\
White B & 2615 & 188 \\
White C & 3025 & 202 \\
White D & 2358 & 177 \\
\hline
\end{tabular}

\section{Results}

As demonstrated in tables $\mathrm{I}-\mathrm{V}$, there was a statistically significant difference of diabetic and normal placentas in the majority of the parameters measured and calculated. In the comparison of diabetic placentas to normal placentas, there was a statistically significant increased cross sectional surface of terminal villi $(\mathrm{p}<0.05)$ and a statistically significant increased villous circumference $(\mathrm{p}=<0.01)$ (table I). It must be pointed out that there is an increase of the values from White groups A to $\mathrm{C}$ as compared with the remarkably lower values in White group D (table I). When the results were grouped in the White classes $A-D$ no statistical analysis was found because of the small number of cases. An obvious trend could be observed although significance was not reached.

The classification in groups of $3000 \mu^{2}$-steps shows a clear shift to the classes of larger villi ( $\mathrm{p}<0.001)$, particulary from White groups A to $C$; whereas, the values of the terminal villi in White group D resemble more closely the values of the control group (table II).

2 The average sum of the cross sectional surfaces of all villous vessels is moderately (but not statistically significant) diminished in the diabetic placenta. Only in White class B is there a substantial decrease in the surface of the villous

Table II. Results of histometric measurements, normal placentas compared with diabetic placentas and classified after White; classification of size of terminal villi.

\begin{tabular}{llll}
\hline & \multicolumn{2}{l}{ Size of terminal villi } \\
\cline { 2 - 4 } & $<3000 \mu^{2}$ & $3000-6000 \mu^{2}$ & $>6000 \mu^{2}$ \\
\hline Normal & 86 & 14 & 0 \\
Diabetes & 72 & 25 & 3.3 \\
Complete (\%) & & & $\mathrm{p}<0.001$ \\
\hline White A & 74 & 23 & 2.5 \\
White B & 69 & 27 & 3.8 \\
White C & 62 & 29 & 8.5 \\
White D & 73 & 24 & 2.8 \\
\hline
\end{tabular}


Table III. Results of histometric measurements, normal placentas compared with diabetic placentas and classified after White; size and number of the villous vessels.

\begin{tabular}{llll}
\hline & $\begin{array}{l}\text { Cross section surface of } \\
\text { the villous vessels }\left(\mu^{2}\right)\end{array}$ & $\begin{array}{l}\text { Circumference of the } \\
\text { villous vessels }(\mu)\end{array}$ & $\begin{array}{l}\text { Number of the villous } \\
\text { vessels }\end{array}$ \\
\hline Normal & 650 & 200 & 4.5 \\
Diabetes complete & 631 & 168 & 3.5 \\
& NS & $\mathrm{p}=0.001$ & $\mathrm{p}<0.001$ \\
\hline White A & 612 & 166 & 3.6 \\
White B & 386 & 127 & 3.1 \\
White C & 880 & 206 & 3.8 \\
White D & 724 & 181 & 3.7 \\
\hline
\end{tabular}

vessels, whereas in White classes $C$ and $D$ we measured a higher value than in normal placentas. This holds also true for the circumferences of the vessels $(p=0.001)$.

Table IV. Results of histometric measurements, normal placentas compared with diabetic placentas and classified to White; degree of vascularization in the terminal villi.

\begin{tabular}{ll}
\hline & Degree of vascularization (\%) \\
\hline Normal & 30.5 \\
Diabetes complete & 27.0 \\
& NS \\
\hline White A & 26.7 \\
White B & 16.0 \\
White C & 31.0 \\
White D & 31.0 \\
\hline
\end{tabular}

The number of the vessels in diabetic placentas is significantly decreased ( $p \leqq 0.001)$, most often expressed again in White group B (table III).

From these parameters the degree of vascularization is calculated. It demonstrates, except for White group B, no marked differences (table IV).

The length of the epithelial plates and their part of the villous circumferences are triflingly increased in patients with diabetes mellitus. There is an interesting constant decline in the values of White classes $A$ to $C$. The values of White group D correspond to those of White group A. The number of epithelial plates is significantly diminished in diabetic placentas $(p$ $<0.001$ ) with a decline from White $A$ to $C$ and an increase to White $\mathrm{D}$ (table V).

Table V. Results of histometric measurements, normal placentas compared with diabetic placentas and classified after White; values of parameters of epithelial plates.

\begin{tabular}{llll}
\hline & $\begin{array}{l}\text { Length of epithelial } \\
\text { plates }(\mu)\end{array}$ & $\begin{array}{l}\text { Number of epithelial } \\
\text { plates }\end{array}$ & $\begin{array}{l}\text { Part of epithelial plates of the } \\
\text { villous circumference (\%) }\end{array}$ \\
\hline Normal & 32 & 2.6 & 18 \\
Diabetes complete & 36 & 1.9 & 21 \\
& $\mathrm{p}<0.05$ & $\mathrm{p}<0.001$ & $\mathrm{NS}$ \\
\hline White A & 38 & 2.0 & 22 \\
White B & 30 & 1.7 & 17 \\
White C & 29 & 1.6 & 16 \\
White D & 38 & 2.0 & 23 \\
\hline
\end{tabular}




\section{Discussion and conclusion}

Formation and numerical increase of the terminal villi, an increased degree of vascularization and formation of the epithelial plates (essential for fetomaternal exchange) are criteria for a normal differentiation of the placenta.

Our results of increasing cross sectional surfaces of terminal villi in diabetic pregnancies are in agreement with those of BJörK [2], HAUST [4] and LAURETi [7]. GePPERT [3] also found bigger terminal villi which correlated better to blood glucose levels than to White classes. In table I the increasing surface area of White group $\mathrm{A}$ to $\mathrm{C}$ and the considerable decline in White group D is presented. Other authors [11, $15,16]$ found similar results, whereas SINGER [13] observed no differences. Haust [4] described somewhat normal placentas and SEMMLER [11] failed to find any differences in White group D. This corresponds well to our finding of only minor differences in this group.

Because of histometric variations in the different diabetic stages the selection of the placentas for morphometric studies classified from the medical records according to White is of paramount importance. Negligence of the different areas of the placenton, when selecting the terminat villi for measurement, may also contribute negatively to the results.

Classification of the terminal villi according to their size demonstrates the differences within the White classes (table II).

Whereas the number of vessels is significantly diminished in diabetic placentas, the overall vessel surface, is except for White group B, not markedly decreased, as was described by Geppert [3] and Shadmi [12]. Only Teasdale [15] has noted increased vessel surfaces. We were unable to confirm the results of ASMUSSEN [1], who reported many small vessels with maternal angiopathy as a sign of proliferative angiopathy in the placentas. As Teasdale [15], we found a degree of vascularization (table III), except for White group B, only moderately different from the control group. We observed as reported by SHADMI [12], a diminished num- ber of epithelial plates including their length and quota of villous circumference however are triflingly increased (table V). When grouped according to White, the constant decline from group $\mathrm{A}$ to group $\mathrm{C}$ and the value to White group D corresponding to White group $\mathrm{A}$ is remarkable.

The results of our study undoubtedly demonstrate a marked retardation of the diabetic placenta, which increases from White group A to C. The disturbances of differentiation relate to different histological structures in each of the White groups: in diabetes of group B mainly vascularization, in White group $C$, mainly size of villi and formation of epithelial plates are affected. The aspect of maturitas retardata is most pronounced in White classes B and C. It is less remarkable in White class A, probably because of the short duration of disease and the absence of marked blood glucose variations. Most interesting are the results of placentas of White class D. In these cases apparently an early compensatory mechanism ensues, expressed by an extensive formation of terminal villi. This phenomenon could be explained as compensatory reaction of the fetal organ placenta, induced by the diminished utero-placental perfusion with decreased oxygen and nutritional supply. The reason may be the maternal diabetic angiopathy which is also evident in the uterine vessels. In rare cases small-for-gestational age infants will be born by White $D$ classified mothers [9]. This fact shows the insufficiency of this morphometricly demonstrable compensatory mechanism of the placenta in many cases.

Apart from the instability of blood glucose levels, elevated blood lipid values and newly discussed immunological phenomena of the diabetic pregnant women, the extreme high fetal jeopardy can be explained by the concomitant pathologic changes in the placenta.

The current study shows that the morphologic signs of placental dystrophy in diabetes are clearly related to the severity and extent of the diabetes as measured by the White classification. In contrast, GEPPERT [3] has suggested 
that the degree of placental dysmaturity in diabetes is mainly influenced by the variability of the blood sugar level during pregnancy. We are currently investigating this question in a new study with a larger number of cases. Preliminary results indicate that there is no significant relationship between metabolic control of the blood sugar levels and placental retardation. Based on our preliminary data we have concluded that fetal macrosomatia and post partum morbidity (hypoglycemia, respiratory distress syndrom and infections) are related to the degree of metabolic control of the blood sugar level. On the other hand, it appears that the intrauterine morbidity (placental insufficiency, intrauterine death) is directly related to the severity of maternal diabetes, as measured by the White classification. This is supported by the fact that in the current series, 13 out of
22 examined diabetic pregnancies demonstrated signs of placental insufficiency such as decreased estrogen excretion and abnormal fetal heart rate patterns. On the other hand, neither in the current study, nor in the study to be published, was there a difference in fetal outcome mainly because diabetic pregnancies are closely followed in our institution and terminated if signs of fetal distress become apparent.

Considering our results, optimal blood glucose regulation in pregnancy may not provide the obstetrician with sufficient security as far as the fetal situation is concerned. Hospital monitoring with all its wellknown possibilities is mandatory for our diabetic patients in the last weeks of pregnancy to detect placental insufficiency early and to minimize fetal morbidity and mortality.

\section{Summary}

In this morphometric study, terminal villi of 22 placentas of maternal diabetes mellitus were compared with the results in terminal villi of 22 normal placentas. The results demonstrate that there is a distinct retardation in maturation, statistically significant with bigger cross sectional surfaces of the terminal villi, particularly, when classified in $3000 \mu^{2}$-steps, the number of the villous vessels and number of epithelial plates. Only slightly decreased in diabetic placentas is the villous vessels cross sectional surface as well as the degree of vascularization. The correlation between the degree of histometric changes and the severity and duration of the disease was separately investigated (classification was done according to White). It could be shown, that the degree of morphologic changes in the terminal villi does not run strictly parallel to the severity and duration of diabetes. The retardation in maturation of the terminal villi increases from White group $A$ to $C$. In White group $D$, which is the most severe stage of diabetes mellitus which we investigated, the values of measured parameters are close to the normal placentas. This observation is interpreted as a compensatory reaction of the fetal organ placenta to the reduction in utero placental blood flow in diabetics caused by the diabetic angiopathy.

Keywords: Diabetes mellitus, morphometry, placenta, White classification.

\section{Zusammenfassung}

Vergleichende morphometrische Untersuchungen an Terminalzotten bei Diabetes mellitus-Plazenten in Abhängigkeit vom White-Stadium

In einer morphometrischen Studie wurden die Endzotten von 22 Plazenten von Müttern mit Diabetes mellitus mit den Endzotten von 22 Terminplazenten stoffwechselgesunder Mütter verglichen. Die Ergebnisse zeigen eine deutliche Reifungsretardierung. Die Zottenquerschnittsfläche ist beim Diabetes signifikant größer, was besonders bei der Klassifizierung in $3000 \mu^{2}$-Schritten zum Ausdruck kommt. Die Anzahl der Zottengefäße wie auch die Anzahl der Epithelplatten ist signifikant kleiner, während die Gefäßquerschnittsfläche und der Vaskularisationsgrad nur mäßig verringert sind.
Der Zusammenhang zwischen dem Ausmaß der Reifungsstörungen und dem Schweregrad und der Dauer der Erkrankung (Einteilungsschema nach White) wurde gesondert untersucht. Der Grad der Zottenreifungsstörungen verändert sich nicht streng parallel zur Schwere und Dauer des Diabetes mellitus. Die Retardierung nimmt vom Stadium White $A$ nach $C$ zu, hingegen kommt die Ausdifferenzierung der Endzotten beim Stadium White $\mathrm{D}$ als dem schwersten von uns untersuchten Krankheitsstadium derjenigen von Normalplazenten am nächsten. Dies wird als Reaktion der Placenta gedeutet, präplazentare Durchblutungsstörungen bei mütterlicher Angiopathie im Stadium White D zu kompensieren.

Schlüsselwörter: Diabetes mellitus, Morphometrie, Plazenta, White-Klassifikation. 


\section{Résumé}

Exploration morphologique des villosités placentaires terminales chez les diabétiques en fonction de la classification de White

On a comparé par une étude morphologique les villosités terminales provenant de 22 placentas de mères atteintes de diabète sucré avec les résultats de l'étude des mêmes villosités provenant de 22 placentas normaux. Les résultats montrent qu'il existe un retard net de maturation, statistiquement significatif quant à l'augmentation de la surface des coupes de villosités terminales tout particulièrement en comptant sur des fragments de $3000 \mu^{2}$ le nombre de vaisseaux villositaires et le nombre de fragments épithéliaux. La surface des sections de vaisseaux villositaires ainsi que le degré de vascularisation ne sont que légèrement diminués dans les placentas de diabétiques.

Mots-clés: Classification de White, diabète sucré, étude morphologique, placenta.
On a exploré séparément la corrélation entre le degré des modifications histométriques et la durée de la maladie (classée selon White). On a pu observer que le degré des modifications morphologiques au niveau des villosités terminales n'est pas strictement parallèle à la gravité et à la durée du diabète. Le retard de la maturation des villosités terminales augmente de la classe $\mathrm{A}$ à la classe C. Dans le groupe D de White, ce groupe représente le stade le plus grave du diabète que nous avons exploré, les valeurs des paramètres mesurés se rapprochent de celles des placentas normaux. On interprête cette observation comme une réaction de compensation du placenta en tant qu'organe fotal à la réduction du débit sanguin utéro-placentaire seondaire à l'angiopathie diabétique.

\section{References}

[1] Asmussen I: Vascular Morphology in Diabetic Placentas. Contrib Gynecol Obstet 9 (1982) 76

[2] BJÖRK O, B PERSSON: Villous Structure in different parts of the Cotyledon in Placentas of InsulinDependent Diabetic Women. A morphometric study. Acta Obstet Gynecol Scand 63 (1984) 37

[3] GePPERT M, FD Peters, J GePPERT: Zur Histomorphometrie der Zottenvaskularisation von Plazenten diabetischer Mütter. Geburtshilfe Frauenheilkd 42 (1982) 628

[4] Haust MD: Maternal Diabetes Mellitus-Effects on the Fetus and Placenta. In: NAYE RL, JM KisSANE (eds): Perinatal diseases, $\mathrm{p}$ 201. Williams and Wilkins, Baltimore-London 1981

[5] Kitzmiller JL, JP Cloherty, MD Younger, A TABatabail, SB RothChILD, I SOSENKo, MF Epstein, S Singh, RK Neff: Current Developments. Diabetic pregnancy and perinatal morbidity. Am J Obstet Gynecol 131 (1978) 580

[6] KoHLHOFF R: Zur perinatalen Morbidität von Kindern diabetischer Mütter - eine Analyse des Krankengutes von 1960-1980. Padiatr Grenzgeb 21 (1982) 259

[7] LAURETI E: Osservazioni istologiche sui villi coriali di placente diabetiche. Boll Soc Ital Biol Sper LVIII (1982) 695

[8] Noack EJ, F Stoz, RA Schuhmann: Morphometrische Untersuchungen an Plazentazotten. Z Geburtshilfe Perinatol 185 (1981) 155

[9] SCHMid J, J KunZ, R SutTer: Diabetes und Schwangerschaft. Gynakol Rundsch 24 (1984) 197
[10] Schummann R.: Die funktionelle Morphologie der Plazentone reifer menschlicher Plazenten. Organisation Gestosis Press, Basel 1976

[11] Semmler K, P Emmrich, K Fuhrmann, E GöDel: Reifungsstörungen der Plazenta in Relation zur Qualität der metabolischen Kontrolle während der Schwangerschaft beim insulinpflichtigen und Gestationsdiabetes. Zentralbl Gynakol 104 (1982) 1494

[12] SHADMI AL, C BaHARI: Histochemical study of Diabetic Plancentae. Results. In: SCHENKER JG, ET RIPPMANN, D WeINSTEIN (eds): Recent advances in pathophysiological conditions in pregnancy. Elsevier Science Publishers, Amsterdam 1984

[13] Singer DB, ChT Liu, JA Widness, RA Ellis: Placental Morphometric Studies in Diabetic Pregnancies. Placenta 3 (1981) 193

[14] Stoz F: Morphometrische Untersuchungen an Resorptionszotten reifer menschlicher Plazenten. Dissertation Ulm 1979

[15] Teasdale F: Histomorphometry of the Human Placenta in Class B Diabetes Mellitus. Placenta 4 (1983) 1

[16] Teasdale F: Histomorphometry of the Human Placenta in Class C Diabetes Mellitus. Placenta 6 (1985) 69

[17] WhITE P: Classification of obstetric diabetes. Am J Obstet Gynecol 130 (1978) 228

Received August 11, 1986. Revised November 11, 1986. Accepted November 13, 1986.

Dr. med. Frank Stoz

Universitäts-Frauenklinik Ulm Prittwitzstraße 43

D-7900 Ulm, West Germany 